\title{
Modernization of Ecology for Handling Abrasion in Riau Province
}

\author{
Fajriani Ananda \\ Riau University, Pekanbaru, Riau, Indonesia \\ Email: fajriani.ananda7404@grad.unri.ac.id
}

\section{ARTICLE INFO}

Received: 05-01-2022

Revision: 13-01-2022

Received : 18-01-2022

\section{Keywords:}

Ecological modernization; abrasion; coastal; environmental management

\begin{abstract}
Abrasion on the coast of Riau Province is becoming a serious problem that has not found an effective solution. The development of breakwaters and mangrove rehabilitation has not provided maximum benefits for the environment and society. The research was conducted in Mekong Village, West Tebingtinggi District, Meranti Islands Regency. The purpose of the study looked at how the model handled abrasion in the study area. Using a qualitative approach conducted interviews with the public, stakeholders and experts in the field of environment. Our results found there is a paradigm of handling abrasion that is wrong by making walls using both organic and plastic waste. This method has not shown effective results in withstanding ocean waves and preventing abrasion. However, in terms of environmental models handling abrasion with garbage deposits actually pollute the environment. To handle abrasion well we argue more modern ways are needed or apply the concept of ecological modernization. The concept integrates modern science and technology from industrial societies to repair damaged or threatened environments. Ecological modernization as well as being a sustainable development effort in the field of environment, especially coastal. The application of ecological modernization is challenged including the orientation of thinking that has not been in favor of modern concepts, softfkill limitations, capital, and stakeholder support. This portrait shows the need for stakeholder intervention and cohesiveness in supporting and implementing ecological modernization in handling abrasion to be more effective and efficient.
\end{abstract}

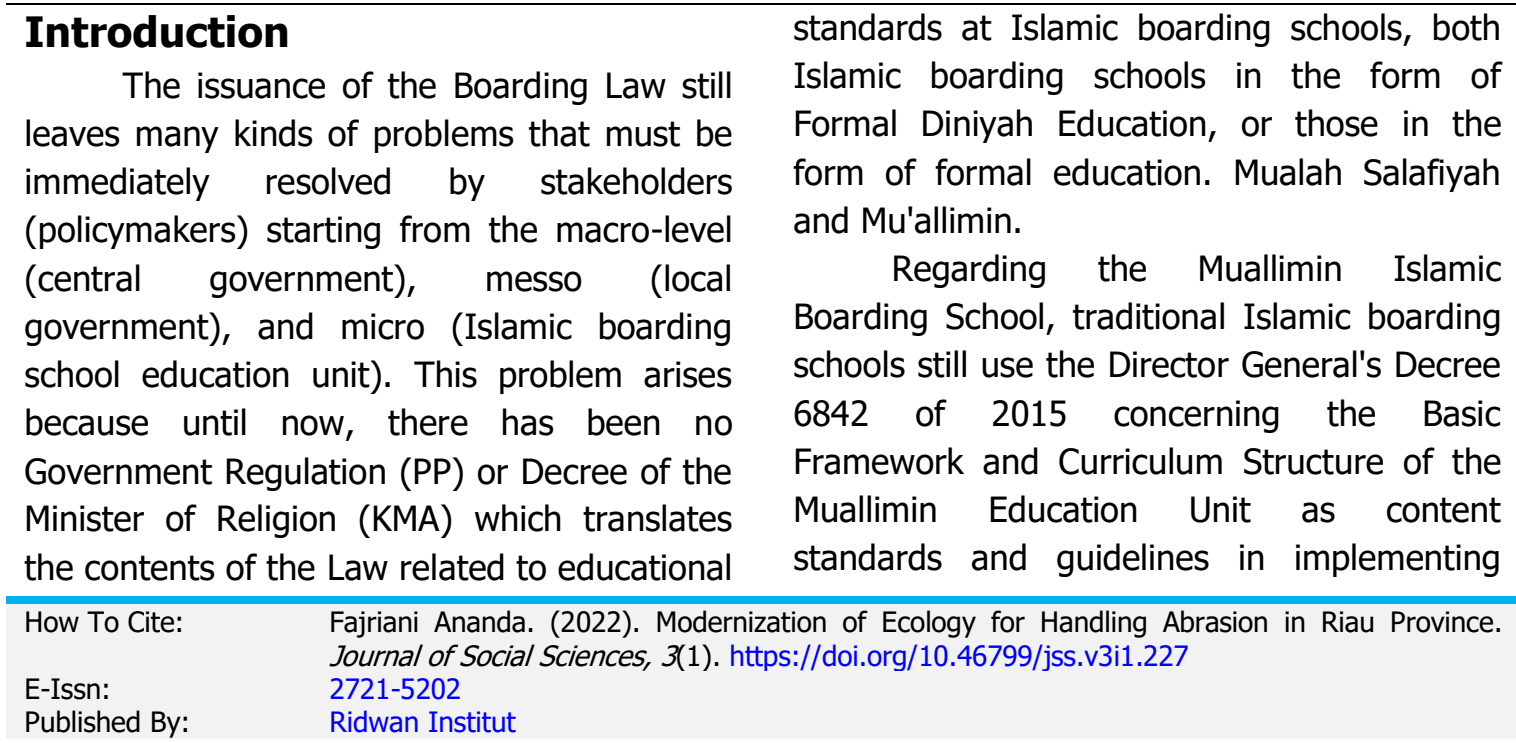


learning programs. However, if we look more deeply between Law. No. 18 of 2019 and the Director General's Decree 6842 of 2015 there are inconsistencies in them, wherein the curriculum document has not entirely directed the goals of the pesantren. This is based on: (1) curriculum development has not been oriented to students' interests. This has resulted in the curriculum being developed in such a way that students master several knowledge, abilities, skills; not designed to provide opportunities for students to develop personalities and skills that can be used to fulfill various life interests (physical, moral, mental) and create social life; (2) Basic Competencies in the cognitive domain of Ulya level, 4th grade TMI, 5 TMI, and 6 TMI (high school level) are still at the level of understanding and application, not leading to the level of analysis. This has an impact on learning that is still dwelling on low-order thinking skills (Low Order Thinking Skills), not yet on high-order thinking skills (High Order Thinking Skills); (3) there are weaknesses in the preparation of Basic Competencies at each level. The Basic Competencies contained in the Director General's Decree include only 3 to $5 \mathrm{KD}$ in the Core Competencies of the cognitive domain in one year. With such a small number of essential competencies, the teachers are confused when the material has been discussed; (4) curriculum engineering is centralized and does not empower the role of pesantren and community participation. This impacts the frequent occurrence of differences in the perception of the vision and mission to be achieved by Islamic boarding schools.

Based on preliminary research on several Islamic boarding schools in West Java, including study conducted by Abdul Hakim and N. Nani Herlina that: (1) in terms of input, there are some ustaz that do not meet academic qualification standards, infrastructure facilities are inadequate, and the budget (funds) is insufficient for education financing; (2) in terms of the educational process, the management of the pesantren curriculum is still not well organized, there has never been accreditation for pesantren by the Ministry of Religion, there is less standardized learning planning, the management of the learning process is less effective, the use of learning methods is less varied, the assessment of learning outcomes is not appropriate procedures for professional learning assessment systems, less than optimal guidance and supervision, and efforts of regular guidance and supervision by the Ministry of Religion, supervisors, and leaders of Islamic boarding schools are still not given much attention; (3) and in terms of output, the pesantren has not opened up the spread of alumni to continue to higher education, especially Ma'had Ali, and has not accommodated pesantren graduates in the college admissions application system.

The Al Basyariyah Islamic Boarding School in Bandung and the Darus Salam Garut Islamic Boarding School are Gontor alumni boarding schools that have obtained a musical (equivalent) type of converts according to the Ministry of Religion's Operational Permit Decree 2852 of 2015. In implementing the curriculum, both Islamic boarding schools use the TMI (Tarbiyatul Muallimin al Islamiyah) program, which is an integration between the salafiyah (traditional) and khalafiyah (modern) education systems. The focus of the applied study consisted of four primary studies, namely $30 \%$, linguistics $47 \%$, and general lessons $23 \%$. This shows that the orientation of the Islamic boarding school is to produce students who understand Islam directly from the source (the yellow book literature and are considered Islamic), supported by the strengthening of the Arabic language. The learning method applied is mubasyarah (direct way), which focuses on student-centeredness. Santri must be active in learning, look for vocabulary that they do not understand, and try to express the book's intentions, both spoken and written, by using Arabic as the language of instruction. 
When viewed from the curriculum structure, the learning load of students in the Islamic religious science subject group varies at each level, ranging from 9 hours to 13 hours of lessons per week out of a total of 34 hours of classes per week. When compared to the number of MTs curriculum structures which amount to 46 hours and MA 51 hours per week, Islamic boarding schools need to think about filling the time void of the students so that their time while at the boarding school is more effective. The two pesantren carry out curriculum management that focuses on Islamic religious knowledge and Arabic. About the control of the curriculum for the study of Islamic religious education, the sources used by these two huts are the yellow book and are considered Islamic. However, in practice in the field, there are still many shortcomings in managing the Islamic religious science curriculum, starting from the curriculum planning stage to the evaluation stage.

On that basis, this study aims to find: (1) planning Islamic religious science curriculum; (2) organization of Islamic religious science curriculum; (3) implementation of Islamic religious science curriculum; (4) evaluation of Islamic religious science curriculum; (5) obstacles in implementing the Islamic religious science curriculum; (6) solutions and future improvement efforts in implementing the Islamic religious science curriculum.

Islamic religious science curriculum management combines three syllables, namely: leadership, curriculum, and Islamic religious studies. The meanings of these three terms need to be explored one by one to understand the combination of these three terms.

First, the definition of management. Linguistically, this word is taken from English, namely 'management.' In the Oxford dictionary, it is stated that management is "the act of running and controlling a business or similar organization," or "The people who run and control a business or similar organization," or "the act or skill of dealing with people or situations successfully." From the three definitions above, the word management implies the activities carried out by a person in exercising control over a business or organization to get a path of success.

Second, the definition of curriculum. At first, the Greeks used the word curriculum in sports, which came from' cure. The term means the distance runners must cover from start to finish to get a medal or award. This expression was later used in education to show the meaning of several subjects (subjects) that must be studied and occupied by a student from the beginning to the end of the school program to obtain an award in the form of a diploma. On the other hand, "the term curriculum in Arabic means 'manhaj', which is a bright path, or a bright path that humans traverse in every space of their movement. In education, curriculum means a clear way that educators or teachers with students travel to develop knowledge, skills, attitudes, and values.

According to (Lazwardi, 2017) there are three concepts about the curriculum, namely the curriculum as a substance, a system and as a field of study.

The curriculum formulations put forward by education experts seem to vary. However, from some of these definitions, common ground (qadr al musytarak) can be found. On the one hand, some experts view the curriculum as the content of lessons. On the other hand, some experts consider the process of experiential learning.

The curriculum's classical understanding emphasizes the lesson's content, such as the opinion of (M Arief 2017) who says, the curriculum is "several subjects or courses at school or college that must be taken to achieve a diploma or level." Or, according is limited to "knowledge put forward by the teacher in the form of subjects or books by scholars that have been studied for so long by students in each stage of their education." Likewise, the definition of 
curriculum is contained in the Act. No. 20 of 2003 "a set of plans and arrangements regarding the objectives, content, and learning materials as well as the methods used as guidelines for implementing learning activities to achieve certain educational goals (Fahlevi, Ritonga, \& Nasution, 2021)."

As for the modern understanding of the curriculum, Caswell and Campbell put forward in (Amin, Sugiatno, \& Fathurrochman, 2019) that the curriculum: '... to be composed of all the experiences children have under the guidance of teachers". This is reinforced by the thoughts of Ronald C. Doll in (Amin et al., 2019), who says that: "... the curriculum has changed from the content of courses study and list of subjects and courses to all experiences which are offered to learners under the auspices or direction of the school". Meanwhile, George A. Beauchamp stated that 'A Curriculum is a written document that may contain many ingredients, but it is a plan for pupils' education during their enrollment in a given school (Amin et al., 2019).'

Of the many expert definitions of the curriculum, it can be said that the curriculum that emphasizes content departs from the assumption that society is static (jumped), while education functions to maintain, maintain, care for, and pass on existing knowledge, concepts, and values, both religious values. (Sahrawi) and human values (worldly). Thus, the curriculum is designed by a group of experts systematically and logically by disciplines that are considered to have been established, without involving teachers, let alone students. Departing from that description, the teacher's task is only as a curriculum implementer at the level of the educational field, starting from content standards, methods, and evaluations. The teacher plays an active role as a provider of information in scientific disciplines, while students are passive recipients of information and tasks from the teacher.

The curriculum that emphasizes the process of learning experience departs from the assumption that since birth, students have had many potentials, ranging from the possibility to Think, Act, solve problems, be creative, develop businesses, and so on. Educational vehicles are created to accommodate all these potentials and develop them according to the interests and talents of students. Thus, the curriculum is designed based on the needs and interests of students. Teaching materials are selected according to their interests and needs. Students become subjects of education in the sense that they occupy the principal place in education. In this case, the teacher is required to act as if he were a psychologist who must understand all the needs and problems of students. The teacher also acts as a midwife who always helps students produce brilliant ideas. Teachers carry out curriculum development by involving students. There is no standard curriculum, there is only a minimal curriculum developed with students, and the learning process is constantly changing according to the interests and needs of students.

Research on the curriculum is constantly evolving in line with the development of educational theory and practice. With the various formulations and limitations regarding the definition of curriculum, it doesn't seem very easy to determine an understanding that can summarize all the opinions of curriculum experts.

From the two definitions above, the term curriculum management is strung together. Before formulating the definition of the term, several education experts have defined curriculum management, such as (Idris, 2018) who says that curriculum management is "a cooperative, comprehensive, systemic, and systematic curriculum management system to realize the achievement of curriculum goals." In line with this, (Utami, 2018) argues that curriculum management is "a system of managing or structuring the curriculum in a cooperative, comprehensive, systemic and systematic way that is used as a reference by educational 
institutions to realize the achievement of curriculum goals or educational goals". Likewise, the Ministry of (Kofod, 2011) defines curriculum management as "a process of directing the learning process to run well as a benchmark for achieving teaching goals by teachers".

Based on the description above, the management of Islamic religious science curriculum can be formulated as a planned, measurable, and systematic effort through planning, organizing, implementing, and evaluating curriculum activities regarding the objectives, content, and learning materials of Islamic religious studies, as well as the methods used as guidelines-implementation of learning activities to achieve educational goals effectively and efficiently.

The yellow book is often identified with the classical book (turâts). These books are classical scholarly literature with Arabic style and writing systematics that is different from modern books. Some define that it is called the yellow book because it is written on yellow paper. So, if there is a book written on white paper, it will be called a white book, not a yellow book. (Hanani, 2017) gives the formulation of the yellow book as "Islamic religious lessons written in Arabic, Malay, Javanese or other local languages in the archipelago, using Arabic script, written by scholars from the Middle East and also written by domestic scholars." This formulation extends the meaning of the yellow book terminology developed so far, namely Arabic religious books, using Arabic script, which was produced by scholars who were experts in their respective fields in the past, especially those from the Middle East.

The Yellow Book is a reference to Islamic boarding schools where the contents are Arabic and this has become a tradition (Ibrahim, 2015). Indonesia (Azra, 2019).

There are similarities and differences between the terms "yellow book" and "Islamic" tastes. The similarity, both of them study Islamic knowledge that comes from the Al-Quran and As-Sunnah. While the differences are: (1) Judging from the time of writing, the yellow book is the work of classical scholars, while it is considered Islamic written by contemporary scholars. Usually it is the kyai or ustadz of the cottage who writes these works by compiling summaries of books sourced from classical texts as a medium to facilitate the understanding of the students; (2) Judging from the user segment, the yellow book is widely studied and deepened in salafiyah/traditional Islamic boarding schools, while the yellow book is considered to be studied in modern Islamic boarding schools.As for the scientific branch, both the yellow book and Islamic teachings cover no less than 12 kinds of scientific disciplines: nahwu, sharf, balanghai, monotheism, fiqh, shul figh, award fiqhiyah, tafsir, hadith, muthalah al-hadithah, tasawuf, and magnetic.

The books that become the concentration of knowledge in Islamic boarding schools are: the branch of fiqh; 1) Safinah as Salah, 2) Safinah al Najah, 3) Fath al Qarib, 4) Taqrib, 5) Fath al Mu'în, 6) Minhaj al Qawim, Muthma'innah, 8) Al Iqna ', 9) Fath al Wahhab. The branch of monotheism; 'Aqidah al Awwam (nazham), 2) Badu al 'Amal (nazham), Sanusiyah. Branch of Sufism; Al-nasha'ih ad Diniyah, 2) Ersyad al 'Ibad, 3) Tanbih al Ghafilin, 4) Minhaj al Abidin, 5) Al Dawa'al Tammah, 6) Al Hikam, 7) Risalah al Mu'awanah wa al Muzhaharah , 8) Bidayah al Hidayah. Branch of nahwusharaf science; Al-Maqsud (nazham), 2) 'Awamil (nazham), 3) 'Imriti (nazham), 4) Ajurumiyah, 5) Kaylani, 6) Mirhat-u'l-I'rab, 7) Alfiyah (nazham), 8) Ibn 'Aqil.

Etymologically, the word mu comes from the Arabic 'âdala yu'âdilu mu'âdalatan, which means equality or equality. Meanwhile, in terms of terminology, the notion of mudalam is an equalization process between educational institutions, both within the pesantren and outside the pesantren, by using standards and quality criteria that have been set in a relatively and open manner. This Islamic boarding school is the oldest 
Islamic educational institution in Indonesia as well as part of the nation's cultural heritage (Syarif, 2018). And according to (Jauhari \& Thowaf, 2019) the history of its spread was through figures who did establish or build Islamic boarding schools as the earliest educational institutions in Indonesia.

This is in line with the meaning contained in the National Education System Law Number 20 of 2003 article 26 paragraph 6 , which states that: "The results of nonformal education can be assessed as equal to the results of formal education programs after going through a process of equivalence assessment by an institution appointed by the government or local government on national education standards.

However, after the issuance of Law no. 18 of 2019, Islamic boarding schools have the same rights as other educational institutions. Diplomas issued by pesantren are equivalent to formal education units. With this diploma, students can continue their education to a higher level. And it is strengthened by a government regulation which states that Islamic boarding schools have received clear recognition that Islamic boarding schools have become educational institutions set by the government. (Hidayat \& Wahib, 2014).

The main objectives of Islamic boarding school education with Madrasah Aliyah and SMA are 1) to provide recognition

\section{Results And Didcussion}

The following is a summary of research findings at the Al Basyariyah Islamic Boarding School in tabular form.

\begin{tabular}{|c|c|c|c|}
\hline NO & Focus & Indicator & Research Findings \\
\hline 1 & $\begin{array}{l}\text { Planning the Islamic } \\
\text { religious science } \\
\text { curriculum based on } \\
\text { the yellow book and } \\
\text { felt Islamiyah at the } \\
\text { muidah Islamic } \\
\text { boarding school. }\end{array}$ & $\begin{array}{l}\text { 1. Objectives } \\
\text { and content } \\
\text { of the } \\
\text { curriculum } \\
\text { 2. Human } \\
\text { Resources } \\
\text { (HR) } \\
\text { 3. Educational } \\
\text { activity } \\
\text { program } \\
\text { 4. Academic } \\
\text { calendar and } \\
\text { scheduling }\end{array}$ & $\begin{array}{l}\text { 1. Objective: To create a generation that is } \\
\text { mutafaqqih fid din. Contents: Integration of } \\
\text { salaf and Khalaf, SK Director-General No. } \\
6842 \text { the year } 2015 \\
\text { 2. Human resources with the same vision as the } \\
\text { cottage, have competence in Arabic and the } \\
\text { yellow book, prioritized Gontor alumni, } \\
\text { minimum qualification of S1. } \\
\text { 3. Extracurricular, extracurricular, co-curricular } \\
\text { activities } \\
\text { 4. Academic calendar: the beginning of new } \\
\text { teaching follows the center. Schedule } \\
\text { arrangement: see the teacher's SKM }\end{array}$ \\
\hline
\end{tabular}

of the existing education system in Islamic boarding schools as required by applicable laws and regulations; 2) obtain an overview of the performance of Islamic boarding schools that will be pioneered or equalized and subsequently used in coaching, developing, and improving the quality and governance of pesantren education; 3) determine the provision of facilities for Islamic boarding schools in providing educational services that are equivalent to Madrasah Aliyah/SMA.

\section{Method}

This research uses a qualitative approach with the type of case studytechnical data collection through in-depth interviews, observation, and documentation. The data collection step is through the orientation, exploration, and member check stages. The data analysis steps are through the stages of data collection, data reduction, data presentation, concluding, and verification. The data validity technique is carried out through reliability, dependability, transferability, and confirmability.

( 


\begin{tabular}{|c|c|c|c|}
\hline NO & Focus & Indicator & Research Findings \\
\hline & & & $\begin{array}{l}\text { (Teaching Readiness Letter), divide into two } \\
\text { fiqh (groups), coordinate with the parenting } \\
\text { section. }\end{array}$ \\
\hline 2 & $\begin{array}{l}\text { We organized the } \\
\text { Islamic religious } \\
\text { science curriculum } \\
\text { based on the yellow } \\
\text { book and considered } \\
\text { Islamic in the } \\
\text { mundane Islamic } \\
\text { boarding school. }\end{array}$ & $\begin{array}{l}\text { 1. Curriculum } \\
\text { organization } \\
\text { patterns } \\
\text { 2. Placement of } \\
\text { Human } \\
\text { Resources } \\
(\text { HR) }\end{array}$ & $\begin{array}{l}\text { 1. The portion of Islamic religious knowledge is } \\
36 \% \text { with the fields of study of the Qur'an, } \\
\text { Hadith, Fiqh, Tawhid, Tarbiyah, Dates. } \\
\text { 2. HR is placed into two parts, ta'lim (learning) } \\
\text { and ri'ayah (nurturing). }\end{array}$ \\
\hline 3 & $\begin{array}{l}\text { The Islamic religious } \\
\text { science curriculum } \\
\text { was implemented on } \\
\text { the yellow book and } \\
\text { considered Islamic } \\
\text { in the mundane } \\
\text { Islamic boarding } \\
\text { school. }\end{array}$ & $\begin{array}{l}\text { 1. Program } \\
\text { socialization } \\
\text { and direction } \\
\text { 2. Preparation of } \\
\text { learning plans } \\
\text { and programs } \\
\text { 3. Determination } \\
\text { of approaches, } \\
\text { strategies, and } \\
\text { learning } \\
\text { methods } \\
\text { 4. Provision of } \\
\text { learning } \\
\text { resources and } \\
\text { media } \\
\text { 5. Class } \\
\text { arrangement }\end{array}$ & $\begin{array}{l}\text { 1. Conducted at the khutbatul 'arsy. activity } \\
\text { 2. Preparation of i'dad at tardis } \\
\text { 3. The learning approach is student-centered, } \\
\text { the strategy is discovery learning using the } \\
\text { mubasyarah method } \\
\text { 4. The source used is the yellow book and is } \\
\text { considered Islamic, audio-visual media } \\
\text { 5. I am separating male and female students, } \\
\text { managing moving classes. }\end{array}$ \\
\hline 4 & $\begin{array}{l}\text { The Islamic religious } \\
\text { science curriculum } \\
\text { was evaluated on } \\
\text { the yellow book and } \\
\text { perceived as Islamic } \\
\text { at the muidah } \\
\text { Islamic boarding } \\
\text { school. }\end{array}$ & $\begin{array}{l}\text { 1. Learning } \\
\text { evaluation, } \\
\text { types, and } \\
\text { evaluation } \\
\text { tools } \\
\text { 2. Evaluation of } \\
\text { yellow book } \\
\text { literacy skills } \\
\text { 3. Evaluation of } \\
\text { communication } \\
\text { skills }\end{array}$ & $\begin{array}{l}\text { 1. Evaluation of summative and formative } \\
\text { learning. Type of test (written, oral), non-test } \\
\text { (observation) } \\
\text { 2. Types of oral test } \\
\text { 3. Types of non-observation and verbal tests }\end{array}$ \\
\hline 5 & $\begin{array}{l}\text { Obstacles in } \\
\text { implementing the } \\
\text { Islamic religious } \\
\text { science curriculum } \\
\text { are based on the } \\
\text { yellow book and } \\
\text { perceived as } \\
\text { Islamiyah. Much } \\
\text { Islamic boarding } \\
\text { school. }\end{array}$ & $\begin{array}{l}\text { 1. Psychological } \\
\text { 2. Sociological } \\
\text { 3. Technical }\end{array}$ & $\begin{array}{l}\text { 1. Santri: Feeling uncomfortable studying at the } \\
\text { cottage, ups and downs in learning } \\
\text { motivation, differences in learning abilities } \\
\text { Teachers: adaptation of the new curriculum } \\
\text { 2. The daily interactions of students and the } \\
\text { demands of parents } \\
\text { 3. Readiness of teachers and students in facing } \\
\text { the new curriculum and content standards in } \\
\text { the Decree of the Director-General of } 6842\end{array}$ \\
\hline 6 & $\begin{array}{l}\text { Solutions and future } \\
\text { improvement efforts } \\
\text { in implementing the } \\
\text { Islamic religious } \\
\text { science curriculum }\end{array}$ & $\begin{array}{l}\text { 1. Psychological } \\
\text { 2. Sociological } \\
\text { 3. Technical }\end{array}$ & $\begin{array}{l}\text { 1. Spiritual approach, providing learning } \\
\text { counseling with foster guardians, building } \\
\text { togetherness in activities inside and outside } \\
\text { the classroom } \\
\text { 2. Conduct weekly evaluation and control }\end{array}$ \\
\hline
\end{tabular}




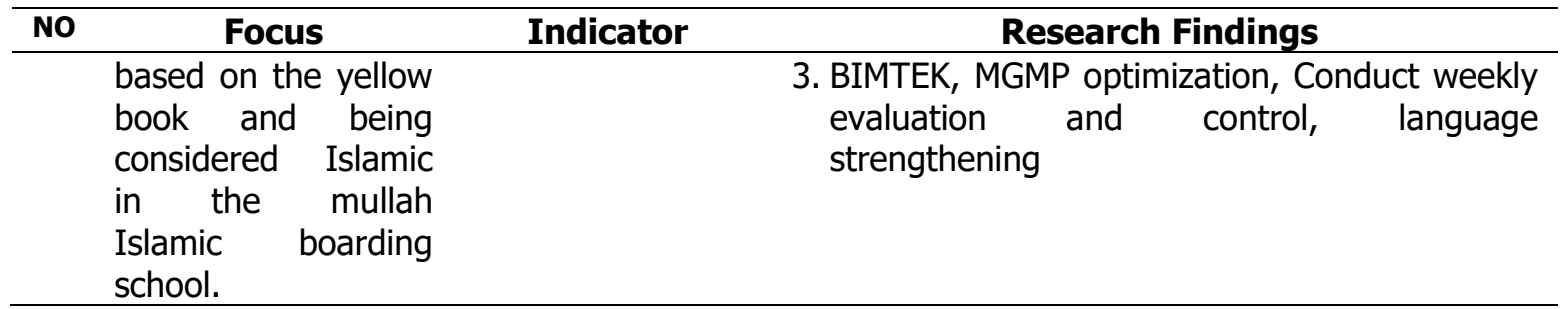

The following is a summary of research findings at the Darussalam Islamic boarding school in tabular form.

\begin{tabular}{|c|c|c|c|}
\hline NO & Focus & Indicator & Research Findings \\
\hline 1 & $\begin{array}{l}\text { I plan the Islamic } \\
\text { religious science } \\
\text { curriculum based on the } \\
\text { yellow book and } \\
\text { considered Islamic in the } \\
\text { mundane Islamic } \\
\text { boarding school. }\end{array}$ & $\begin{array}{l}\text { 1. Objectives and } \\
\text { content of the } \\
\text { curriculum } \\
\text { 2. Human Resources } \\
\text { (HR) } \\
\text { 3. Educational activity } \\
\text { program } \\
\text { 4. Academic calendar } \\
\text { and scheduling }\end{array}$ & $\begin{array}{l}\text { 1. Objective: To create a generation } \\
\text { that is mutafaqqih fid din. Contents: } \\
\text { Integration of salaf and Khalaf } \\
\text { 2. Human resources who share the } \\
\text { same vision as the Islamic boarding } \\
\text { school, have competence in Arabic } \\
\text { and the yellow book, prioritized } \\
\text { alumni of the Gontor boarding } \\
\text { school/alumni, minimum } \\
\text { qualification of S1, mandatory } \\
\text { mukim. } \\
\text { 3. Core and Integrated Curriculum } \\
\text { 4. Academic calendar: the beginning } \\
\text { of a new school follows the center. } \\
\text { Scheduling: col see teacher } \\
\text { qualifications, coordinate with } \\
\text { parenting }\end{array}$ \\
\hline 2 & $\begin{array}{l}\text { I am organizing the } \\
\text { Islamic religious science } \\
\text { curriculum based on the } \\
\text { yellow book and being } \\
\text { considered Islamic in the } \\
\text { mundane Islamic } \\
\text { boarding school. }\end{array}$ & $\begin{array}{l}\text { 1. Curriculum } \\
\text { organization } \\
\text { patterns } \\
\text { 2. Placement of } \\
\text { Human Resources } \\
\text { (HR) }\end{array}$ & $\begin{array}{l}\text { 1. The share of Islamic religious } \\
\text { knowledge is } 36 \% \text { with the fields of } \\
\text { study of the Qur'an, Hadith, Fiqh, } \\
\text { Tawhid, Addin Al Islamic, } \\
\text { Muqaranah al Adyan Tarikh } \\
\text { 2. HR is divided into two parts, } \\
\text { secretaries, TMI, care, waqf bodies, } \\
\text { IKASADA, administration }\end{array}$ \\
\hline 3 & $\begin{array}{l}\text { The Islamic religious } \\
\text { science curriculum was } \\
\text { implemented on the } \\
\text { yellow book and } \\
\text { considered Islamic in the } \\
\text { mundane Islamic } \\
\text { boarding school. }\end{array}$ & $\begin{array}{l}\text { 1. Program } \\
\text { socialization and } \\
\text { direction } \\
\text { 2. Preparation of } \\
\text { learning plans and } \\
\text { programs } \\
\text { 3. Determination of } \\
\text { learning strategies } \\
\text { and methods } \\
\text { 4. Provision } \\
\text { learning resources } \\
\text { and media } \\
\text { 5. Class arrangement }\end{array}$ & $\begin{array}{l}\text { 1. Conducted at the khutbatul 'arsy. } \\
\text { activity } \\
\text { 2. The practice of i'dad at tardis } \\
\text { 3. Discovery learning strategy using } \\
\text { the mubasyarah method } \\
\text { 4. The source used is the yellow book } \\
\text { and is considered Islamic, audio- } \\
\text { visual media } \\
\text { 5. Separating male and female } \\
\text { students, managing moving classes }\end{array}$ \\
\hline 4 & $\begin{array}{l}\text { The Islamic religious } \\
\text { science curriculum was } \\
\text { evaluated based on the } \\
\text { yellow book and } \\
\text { perceived as Islamic at }\end{array}$ & $\begin{array}{l}\text { 1. Learning } \\
\text { evaluation, types, } \\
\text { and evaluation } \\
\text { tools } \\
\text { 2. Evaluation of }\end{array}$ & $\begin{array}{l}\text { 1. Evaluation of summative and } \\
\text { formative learning. Type of test } \\
\text { (written, oral), non-test } \\
\text { (observation) } \\
\text { 2. Types of oral test }\end{array}$ \\
\hline
\end{tabular}




\begin{tabular}{|c|c|c|}
\hline NO & Focus & Indicatol \\
\hline & $\begin{array}{l}\text { the muidah } \\
\text { boarding school. }\end{array}$ & $\begin{array}{l}\text { yellow } \\
\text { literacy skills } \\
\text { 3. Evaluation } \\
\text { communicati } \\
\text { skills }\end{array}$ \\
\hline 5 & $\begin{array}{l}\text { Obstacles in } \\
\text { implementing the Islamic } \\
\text { religious science } \\
\text { curriculum based on the } \\
\text { yellow book and } \\
\text { perceived as Islamiyah at } \\
\text { the muidah Islamic } \\
\text { boarding school. }\end{array}$ & $\begin{array}{l}\text { 1. Psychological } \\
\text { 2. Sociological } \\
\text { 3. Technical }\end{array}$ \\
\hline 6 & $\begin{array}{l}\text { Solutions and future } \\
\text { improvement efforts in } \\
\text { implementing the Islamic } \\
\text { religious science } \\
\text { curriculum based on the } \\
\text { yellow book and being } \\
\text { considered Islamic in the } \\
\text { mullah Islamic boarding } \\
\text { school. }\end{array}$ & $\begin{array}{l}\text { 1. Psychological } \\
\text { 2. Sociological } \\
\text { 3. Technical }\end{array}$ \\
\hline
\end{tabular}

Planning is a series of forward-looking activities to achieve a consistent and coordinated set of operations to obtain the desired results. Planning is a very crucial stage. It is an intellectual process that involves making decisions. This process requires a mental predisposition to think before acting, act based on reality instead of guesswork, and do something regularly.

Based on the research findings, the Al Basyariyah Islamic Boarding School and the Darussalam Islamic Boarding School have planned Islamic religious science curriculum programs starting from the determination of the formulation of curriculum objectives and contents, the preparation of Human Resources (HR), the practice of educational programs, and the academic calendar and schedule of activities. The activities above are steps in the curriculum planning stage. This is in line with what has been formulated by (Hamalik, 2006) that curriculum planning is "planning learning opportunities intended to guide students towards the desired behavioral changes and assess the extent to which changes have occurred in students."

The formulation of curriculum objectives has a function to determine "where" the direction of the pesantren's goals. The formulation of the curriculum content is related to the "what" material that will be given to the students. Preparation of Human Resources (HR) is connected to "who" will oversee the course of this curriculum. The practice of the program is related to "how" to package these materials in the lives of students. The approach of the academic calendar and schedule of activities is related to "how" to organize educational activities so that the boundaries are more apparent. (Fathurrochman, Danim, AB, Kurniah, \& Ristianti, 2021) said: "Curriculum planning at Islamic boarding schools in Indonesia has several stages, namely planning what activities are the goals and activities that must be carried out. So, the curriculum planning implemented in the boarding school is entirely running optimally".

Organizing is the process of organizing the duties, authorities, and responsibilities of 
each individual in management. The organization of the curriculum is intended to answer the question of how the curriculum is selected. The formulated educational goals can influence the curriculum's pattern or design because these goals can determine the way or framework for selecting, planning, and implementing all school experiences and learning activities.

Based on the research findings related to curriculum organization, Al Basyariyah Islamic Boarding School and Darussalam Islamic Boarding School started by making a pattern or design of curriculum organization, then arranging the placement of human resources according to their respective qualifications. This is in line with what was conveyed by (Idris, 2018) that curriculum organization is "a pattern or design of curriculum materials that aims to make it easier for students to learn lesson materials and make it easier for them to carry out learning activities so that learning objectives can be achieved effectively." Curriculum organizing activities are intended to organize and present Islamic religious knowledge comprehensively and systematically. While the placement of human resources is intended to direct the students so that moves like the cottage can run as they should.

The Muslim type curriculum since 2015 has been compiled and documented, which is the Decree of the Director-General of Islamic Education number 6842 of 2015 concerning the Basic Framework and Curriculum Structure of the Muslim Education Unit. This is "documentation of what has been going on in the Muslim in pesantren which is then presented in the form of core and basic competencies" (Ahmad Taufiq, 2019).

The approach used in the organization of competencies between subjects is integral, comprehensive, and independent. Essential competencies in Kulliyatul Mu'allimin al Islamiyah (KMI) or Tarbiyatul Mu'allimin al Islamiyah (TMI) are Islamic sciences, linguistics, and general knowledge.
The fundamental competencies of Ulum Islamiyah include religious attitudes, social attitudes, knowledge, and the implementation of knowledge organized vertically and horizontally in scientific groups, which include subjects of the Qur'an, recitation, interpretation, translation, hadith, hadith science, fiqh, shul figh, inheritance, monotheism. , addin al Islamiy, muqaranah adyan, and Islamic dates. Vertically is an organization of competence in subjects between grade level and above so that there is an accumulation of continuous content that students learn. Horizontally essential competencies between subject content so that between one issue and another, there is a mutually reinforcing process. Generally, linguistic competence consists of reading competence, writing competence, speech competence, and listening competence. To achieve these four competencies, subjects that specifically support their achievement are arranged and sponsored by co-curricular and extracurricular, creating conditions for accelerating the achievement of linguistic competencies, likewise with general knowledge competence. The four competencies of religious attitudes, social attitudes, and application of knowledge are organized vertically and horizontally.

Implementation is a process of applying ideas, concepts, policies, or innovations in practical action to impact changes in knowledge, skills, values, and attitudes. Internal implementation is defined as the actualization of the written curriculum in the form of learning. Learning in the classroom is a place to implement and test the curriculum. In learning activities, all teachers' concepts, principles, knowledge values, methods, tools, and abilities are tested in the form of actions, which will create an actual curriculum (curriculum in action). The embodiment of the curriculum's concepts, principles, and aspects entirely lie in teachers' ability as curriculum implementers. Therefore, teachers act as 
planners, implementers, assessors, and authentic curriculum developers.

Based on research findings related to curriculum implementation, Al Basyariyah Islamic Boarding School and Darussalam Islamic Boarding School carry out implementation stages starting from socialization and direction, preparation of lesson plans, determination of learning strategies, preparation of learning resources, and classroom management. This is in line with the concept of curriculum implementation described by (Hamalik, 2006), namely "all experiences in the educational environment, both planned and unplanned."

Socialization and direction activities are intended to strengthen the goals that have been set. Preparation of lesson plans (i'dad at tardis) as a form of teaching preparation. The action of determining learning strategies to answer questions about what is done in the classroom. The practice of teaching materials is intended to provide support for learning activities. And classroom management is a form of creating a conducive classroom atmosphere.

Evaluation is a performance check to determine how the objectives have been achieved as formulated in the plan. Curriculum evaluation is a systematic effort to collect information about a curriculum to consider the value and meaning of the curriculum in a particular context.

Based on the research findings, the Al Basyariyah Islamic Boarding School and the Darussalam Islamic Boarding School carry out the curriculum evaluation stages, including evaluation of learning, literacy competence, and communication competence. The evaluation is carried out with the principles of being objective, fair, transparent, integrated, and comprehensive. All experiences experienced by students do not escape the assessment, both academic and nonacademic. The evaluation includes cognitive, affective, and psychomotor aspects. This is in line with the concept of curriculum evaluation, according to (Ibrahim dan Masitoh, 2015), which is "a process as well as a tool to determine the value of something based on certain criteria that serve as input for determining a decision."

Learning evaluation activities are related to measuring students' ability about Islamic religious knowledge from their cognitive side. The evaluation of literacy competence is intended to see the extent of their ability to read and understand the yellow book. And the review of literacy competence is intended to determine the ability of students to convey religious messages verbally to the community.

\section{Conclusion}

Planning the Islamic religious science curriculum at the two Islamic boarding schools starts from setting the goals and contents of the curriculum, namely wanting to form individuals who are spiritual experts (mutafaqqih $f i$ addîn) with the range of integration between the salaf and the Khalaf. Second, the determination of Human Resources (HR) uses several criteria, namely HR who have the same vision as the Islamic boarding school, have competence in Arabic and the yellow book, prioritized alumni of Gontor boarding schools, minimum qualifications of S1. Third, the division of integrated education programs in the cottage into three parts, namely extracurricular, cocurricular, and extracurricular. Fourth, the preparation of the academic calendar follows the policy from the center regarding the start of new teachings and semester breaks. At the same time, on national holidays, sometimes the boarding school does not participate because students' activities must continue to run the schedule of activities. Meanwhile, the preparation of the program for the actions of the two Boarding coordinates between the academic and parenting divisions, looking at the qualifications and competencies of teachers.

The organization of the Islamic religious science curriculum starts from the 
pattern of curriculum organization following the curriculum structure contained in the Decree of the Director-General No. 6842 of 2015 concerning Curriculum Structure in Muallimin Education Units and an enriched curriculum incorporating a study of the yellow book. Second, the Human Resources (HR) placement using the principle of "the right man on the right job, the right man on the right place." Empowered Human Resources are directed to two main activities, nurturing and teaching.

Implementing the Islamic religious science curriculum starts from the curriculum's socialization and direction, which is carried out at the beginning of each new teaching in the Khutbatul 'Arsy activity. Second, develop learning plans and programs by making bad trades. Third, determine the student-centered learning approach (studentoriented), the learning strategy applied by discovery learning, and the learning method using tariqah mubasyarah. Fourth is learning resources in the yellow book, Islamic grade readers, and audio-visual learning media. The fifth class arrangement is made by separating male and female students and managing moving classes.

The Islamic religious science curriculum evaluation is divided into three parts: first, the assessment of learning in formative and summative forms, the type of evaluation applied to written and oral tests. Second, literacy evaluation in understanding the yellow book according to the grade level, both in writing and orally. Third, evaluation of communication in the form of traditional mujadara and Aaliyah activities.

Obstacles in implementing the Islamic religious science curriculum can be seen from three factors, namely: first, psychological factors which are marked by the emergence of a feeling of not feeling at home while studying at the boarding school, ups and downs in learning motivation, differences in learning abilities, and their readiness to learn with the new curriculum for students. Al Basyariyah Islamic Boarding School students.
Second, the sociological factor is marked by the emergence of problems in daily interactions between students. Third, the technical aspect is characterized by the teacher's lack of understanding of the content standards in the Director General's Decree 6842 of 2015 concerning the Framework and Structure of the Muallimin Education Unit Curriculum.

Solutions and future improvement efforts in implementing the Islamic religious science curriculum can be seen from three factors according to the above obstacles, namely: first, psychological factors by taking a spiritual approach, tutoring with foster guardians, building togetherness in activities inside and outside the home. Outside the classroom. Second, the sociological factor by conducting weekly evaluations and controls. Third, technical aspects by running BIMTEK, optimizing MGMP, holding weekly assessment and management, strengthening language.

\section{References}

Amin, Muhammad, Sugiatno, Sugiatno, \& Fathurrochman, Irwan. (2019). Pengembangan Keilmuan Program Studi Manajemen Pendidikan Islam Tinjauan Futurologi Pendidikan dan Pengembangan Kurikulum. Tadbir: Jurnal Studi Manajemen Pendidikan, 3(2), 199-225.Google Scholar

Azra, Azyumardi. (2019). Pendidikan Islam: tradisi dan modernisasi di tengah tantangan milenium III. Prenada Media. Google Scholar

Fahlevi, Mhd Reza, Ritonga, Asnil Aidah, \& Nasution, Wahyuddin Nur. (2021). The Relevance of The Madrasah Aliyah Fiqh Package Book Published By The Indonesian Ministry of Religion With The 2013 Curriculum. Nazhruna: Jurnal Pendidikan Islam, 4(2), 460-476. Google Scholar

Fathurrochman, Irwan, Danim, Sudarwan, $A B$, Syaiful Anwar, Kurniah, Nina, \& Ristianti, Dina Hajja. (2021). Theoretical Review of the Implementation Islamic Boarding School Curriculum 
Management in Indonesia. International Journal of Education Research and Development, 1(1), 1-15. Google Scholar

Hamalik, Oemar. (2006). Manajemen pengembangan kurikulum. Sekolah Pascasarjana Universitas Pendidikan Indonesia dengan PT Remaja. Google Scholar

Hanani, Nurul. (2017). Manajemen pengembangan pembelajaran kitab kuning. Realita, 15(2), 1-25. Google Scholar

Hidayat, Ara, \& Wahib, Eko. (2014). Kebijakan Pesantren Mu'adalah dan Implementasi Kurikulum di Madrasah Aliyah Salafiyah Pondok Tremas Pacitan. Jurnal Pendidikan Islam, 3(1), 183-201. Google Scholar

Ibrahim dan Masitoh. (2015). Evaluasi Kurikulum. Dalam Tim Pengembang MKDP Kurikulum dan Pembelajaran. 105-121. Google Scholar

Ibrahim, Rustam. (2015). Bertahan di Tengah Perubahan. Yogyakarta: Sibuku. Google Scholar

Idris, Adinata Rusmen. (2018). PENERAPAN KURIKULUM 2013 DI SMA DAN MA (Tinjauan Manajemen Kurikulum). Jurnal AZKIYA, 1(2), 1-23. Google Scholar

Jauhari, Najib, \& Thowaf, Siti Malikah. (2019). Kesetaraan Gender di Pesantren dalam Kajian Literatur. Sejarah Dan Budaya: Jurnal Sejarah, Budaya, Dan Pengajarannya, 13(2), 179-188. Google
Scholar

Kofod, Klaus Kasper. (2011). Hot Topics, Monograph and the academic journal, Leading and Managing. Jonas Höög is a Professor in Sociology working since 10 years at the Centre for Principal Development at Umea University. He is also a member of the ISSPP research group since 2002 and works in the National Principal Training program, the Masters Program in Educational Leadership, the Masters program in Leadership. How School Principals Sustain Success over Time, 231. Google Scholar

Lazwardi, Dedi. (2017). Manajemen kurikulum sebagai pengembangan tujuan pendidikan. Al-Idarah: Jurnal Kependidikan Islam, Л1), 119-125. Google Scholar

M arief, m. Arief. (2017). Pengembangan kurikulum pendidikan agama islam (Analisis Pemikiran Prof. Dr. Muhaimin MA). University of Muhammadiyah Malang. Google Scholar

Syarif, Zainuddin. (2018). Dinamisasi Manajemen Pendidikan Pesantren; Dari Tradisional Hingga Modern (Vol. 2). Duta Media Publishing. Google Scholar

Utami, Try Septy Tanys. (2018). Implementasi Manajemen Kurikulum 2013 di MTsN Pandeglang Provinsi Banten. Tarbawi: Jurnal Keilmuan Manajemen Pendidikan, 4(02), 275-283. Google Scholar

\section{Copyright holder :}

Fajriani Ananda (2022)

First publication right :

Journal of Social Science

This article is licensed under:

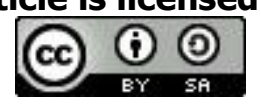

